\title{
PENGEMBANGAN PERANGKAT PEMBELAJARAN IPA MODEL GUIDED INQUIRY UNTUK MELATIHKAN KETERAMPILAN PROSES SAINS DAN MENINGKATKAN HASIL BELAJAR SISWA SMP
}

\author{
Anik Sulistyorini ${ }^{1)}$, Tjandrakirana ${ }^{2)}$, Soetjipto ${ }^{3)}$ \\ ${ }^{1)}$ Mahasiswa Program Studi Pendidikan Sains, Program Pascasarjana Universitas Negeri Surabaya \\ ${ }^{2), 3)}$ Dosen Pascasarjana Prodi Pendidikan Sains Univesrtitas Negeri Surabaya \\ E-mail:Cha2niq_teoryni@yahoo.co.id
}

\begin{abstract}
Abstrak: Telah dilakukan penelitian dengan mengembangkan perangkat pembelajaran (RPP, LKS, Materi Ajar, dan Tes Hasil Belajar) model guided inquiry dengan model pengembangan 4D untuk melatihkan keterampilan proses sains pada pokok bahasan pencemaran lingkungan dengan tujuan meningkatkan hasil belajar siswa. Sasaran penelitian adalah perangkat pembelajaran yang diujicobakan pada 35 siswa SMP dengan rancangan One Group Pretest-Postest Design. Kelayakan perangkat pembelajaran yang dikembangkan dianalisis secara deskriptif kuantitatif-kualitatif dengan hasil : (1) Validitas perangkat kategori valid $(3,00)$; $(2)$ Kepraktisan perangkat yang meliputi: a) Keterlaksanaan baik $(3,8)$; b) Keterbacaan LKS dan buku siswa menyatakan bahwa isi LKS dan buku menarik, c) Respon siswa sangat positif (85,6 \%); (3) Keefektifan perangkat permbelajaran yang meliputi: a) Aktivitas siswa yang menonjol adalah berlatih keterampilan proses sains dengan kategori tinggi $(38,5 \%)$; b) Hasil keterampilan proses siswa dalam mengerjakan LKS sangat tinggi $(3,46)$; c) Hasil belajar siswa meningkat (N-Gain: 0,2-1,0). Simpulan penelitian ini adalah perangkat pembelajaran IPA model guided inqury layak untuk melatih keterampilan proses sains dan meningkatkan hasil belajar siswa SMP
\end{abstract}

Kata kunci: Guided Inquiry, Keterampilan Proses Sains

Abstract: This research was done by developing science learning materials (lesson plans, student's worksheets, student's book, and learning achivement test) based on guided inquiry learning model using 4D development model to facilitate student's science process skills and improving student's learning achivement on environmental pollutions matter. The objective of this research was to trial learning materials in 35 of junior high school's students with one group pretest-postest design. Results were analyzed by descriptive quantitative-qualitative are: (1) Validity of learning material valid category (3.00); (2) Practicalitybased on: a) Feasibility of instruction good category $(3,8)$; b) Readability of worksheets and student's book students stating that the content and appearance of worksheets and student's book is interesting; c) The response of students very positively (85.6\%); (3) Effectiveness based on: a) Student's activities who stand out were practice science process skills is high category (38,5\%); b) Student's science process skill in very high category as shown by student's worksheet achivement $(3,46)$; c) student learning achivement increased (N-Gain: 0.2-1.0). The conclusion of this research that science learning material depeloped base on guided inquiry learnig model, eligible to facilitate student's science process skills and improve student learning achivement in junior high school.

Keywords: Guided Inquiry, Science Process Skill.

\section{PENDAHULUAN}

Pembelajaran adalah kegiatan yang dilakukan oleh guru secara terprogram dalam desain instruksional yang menciptakan proses interaksi antara sesama peserta didik, guru dengan peserta didik dan dengan sumber belajar. Belajar menurut Suprijono (2009), adalah perubahan perilaku yang bersifat permanen sebagai hasil dari pengalaman. Perubahan tingkah laku sebagai hasil belajar menyangkut baik perubahan yang bersifat pengetahuan (kognitif), keterampilan (psikomotor) maupun yang menyangkut nilai dan sikap (afektif). Seiring dengan perkembangan zaman dan kemajuan pendidikan, pemerintah terus menerus memperbaharui kurikulum di Indonesia. Kurikulum yang diberlakukan saat ini adalah Kurikulum 2013. Menurut Kemdikbud (2013) kurikulum 2013 mengamanatkan esensi pendekatan ilmiah dalam pembelajaran, karena pendekatan ilmiah diyakini dapat mengembangkan sikap, keterampilan, dan pengetahuan siswa. Pendekatan ilmiah dapat menjadikan siswa lebih aktif dalam mengkontruksi pembelajaran dan keterampilannya, serta mendorong siswa untuk melakukan penyelidikan guna menemukan fakta dari suatu fenomena kejadian. Penerapan pendekatan ilmiah 
dalam pembelajaran menuntut adanya perubahan setting dan bentuk pembelajaran tersendiri yang berbeda dengan pembelajaran konvensial, sehingga perlu digunakan model pembelajaran yang sesuai dengan prinsip pendekatan ilmiah, salah satunya yaitu guided inquiry.

Guided inquiry merupakan sebuah model yang berfokus pada proses berpikir yang membangun pengalaman oleh keterlibatan peserta didik secara aktif dalam pembelajaran (Kuhlthau, 2007). Model guided inquiry memberikan kesempatan kepada siswa menggunakan pengalaman belajar yang nyata dan aktif serta dilatih bagaimana memecahkan masalah sekaligus membuat suatu keputusan. Guru hanya berperan sebagai fasilitator dalam hal menentukan topik, pertanyaan dan bahan penunjang. Guided inquiry melibatkan siswa dalam proses belajar yang ilmiah layaknya seorang ilmuwan, memecahkan permasalahan dengan observasi, mengumpulkan data secara cermat dan akurat (Olson, 2013).

Pada beberapa materi pelajaran Ilmu Pengetahuan Alam (IPA) dapat dilakukan dengan menggunakan model guided inquiry, misalnya materi pencemaran lingkungan. Dalam materi pencemaran lingkungan siswa dapat terlibat langsung dalammerumuskan masalah, menyelidiki secara luas dan kemudian membangun pemahaman, pengartian dan pengetahuan baru. Berdasarkan pengetahuan baru tersebut, siswa dapat belajar menemukan solusi untuk mengatasi masalah pencemaran lingkungan tersebut secara berkelompok.

Belajar IPA bukan hanya sekedar membahas materi dalam buku-buku pelajaran atau menginformasikan pengetahuan kepada siswa, melainkan menekankan pada pemberian pengalaman secara langsung kepada siswa untuk memahami gejala biologi yang terjadi (Depdiknas, 2004). Pendidikan IPA diharapkan dapat menjadi wahana bagi peserta didik untuk mempelajari diri sendiri dan alam sekitar. Proses pembelajarannya menekankan pada pemberian pengalaman langsung untuk mengembangkan kompetensi agar menjelajahi dan memahami alam sekitar secara ilmiah. Hal penting yang harus dilakukan dalam proses pembelajaran adalah dengan melatihkan keterampilan proses, agar siswa lebih aktif dalam memperoleh sendiri sikap, keterampilan, dan pengetahuannya.

Berdasarkan hasil observasi dan wawancara dengan salah satu guru IPA dan siswa SMP di Surabaya, dalam pembelajaran, guru sudah sering menggunakan model pembelajaran kooperatif, untuk model pembelajaran guided inquiry sudah pernah diterapkan namun dalam pelaksanaannya kurang sesuai, karena kurangnya perangkat pembelajaran yang sesuai untuk melaksanakan pembelajaran model guided inqury, sehingga perlu adanya pembenahan terhadap perangkat pembelajaran model guided inqury dan Kurikulum 2013. Siswa diketahui masih kurang mampu dalam melakukan penyelidikan ilmiah. Siswa masih terpaku pada apa yang disampaikan oleh guru, hanya siswasiswa tertentu yang mampu menerapkan keterampilan proses sains. Hal senada diungkapkan oleh Heuvelen (2001) yang menyatakan bahwa permasalahan yang umum terjadi dalam pembelajaran sains adalah penyajian pengetahuan yang terlalu banyak membahas fakta dan hukum, serta kurang menerapkan metode inkuiri yang efektif untuk menemukan konsep dalam suatu pokok bahasan. Siswa belajar konsep melalui membaca buku atau mendengarkan penjelasan guru. Akibatnya, kepercayaan siswa terhadap sains dibentuk melalui pemberitahuan orang lain, tidak melalui pengamatan atau pemodelan yang dilakukan sendiri.

Kurikulum 2013 mengharapkan dalam proses pembelajaran, siswa ditekankan pada kegiatan-kegiatan ilmiah seperti mengamati, menanya, menalar, mengasosiasi, dan mengkomunikasikan hasil pembelajarannya, sehingga perlu disediakan perangkat pembelajaran yang dapat membantu siswa melakukan kegiatan-kegiatan ilmiah tersebut. Kegiatan ilmiah tersebut erat kaitannya dengan keterampilan proses sains siswa. Alasan keterampilan proses perlu dilatihkan, karena pembelajaran IPA berkaitan dengan cara mencari tahu tentang alam secara sistematis, sehingga pembelajaran IPA bukan hanya penguasaan kumpulan pengetahuan yang berupa fakta-fakta, konsep-konsep, atau prinsip-prinsip saja tetapi juga merupakan suatu proses penemuan.

Menurut Ibrahim (2010), keterampilan proses perlu dikembangkan karena dengan keterampilan proses seseorang akan mampu belajar mandiri, mengembangkan diri sendiri, dan belajar sepanjang hayat. Keterampilan proses sains merupakan keterampilan yang diperlukan dalam melakukan penelitian dan memecahkan masalah. Kemampuan pemecahan masalah ini merupakan salah satu kecakapan hidup (Life skills) yang perlu dimiliki siswa sebagai bekal dalam meneruskan kehidupannya (Mustahal, 2014). Berdasarkan uraian di atas maka penting untuk mengembangkan perangkat pembelajaran IPA model guided inqury untuk melatihkan Keterampilan Proses Sains dan Meningkatkan Hasil Belajar Siswa SMP.

\section{METODE PENELITIAN}

Penelitian ini merupakan jenis penelitian pengembangan, yaitu mengembangkan perangkat pembelajaran yang mengacu pada model pengembangan perangkat 4D (four $D$ model) yang dimodifikasi sesuai kebutuhan. Rancanngan pengembangan perangkat pembelajaran dalam penelitian ini adalah sebagai berikut: 


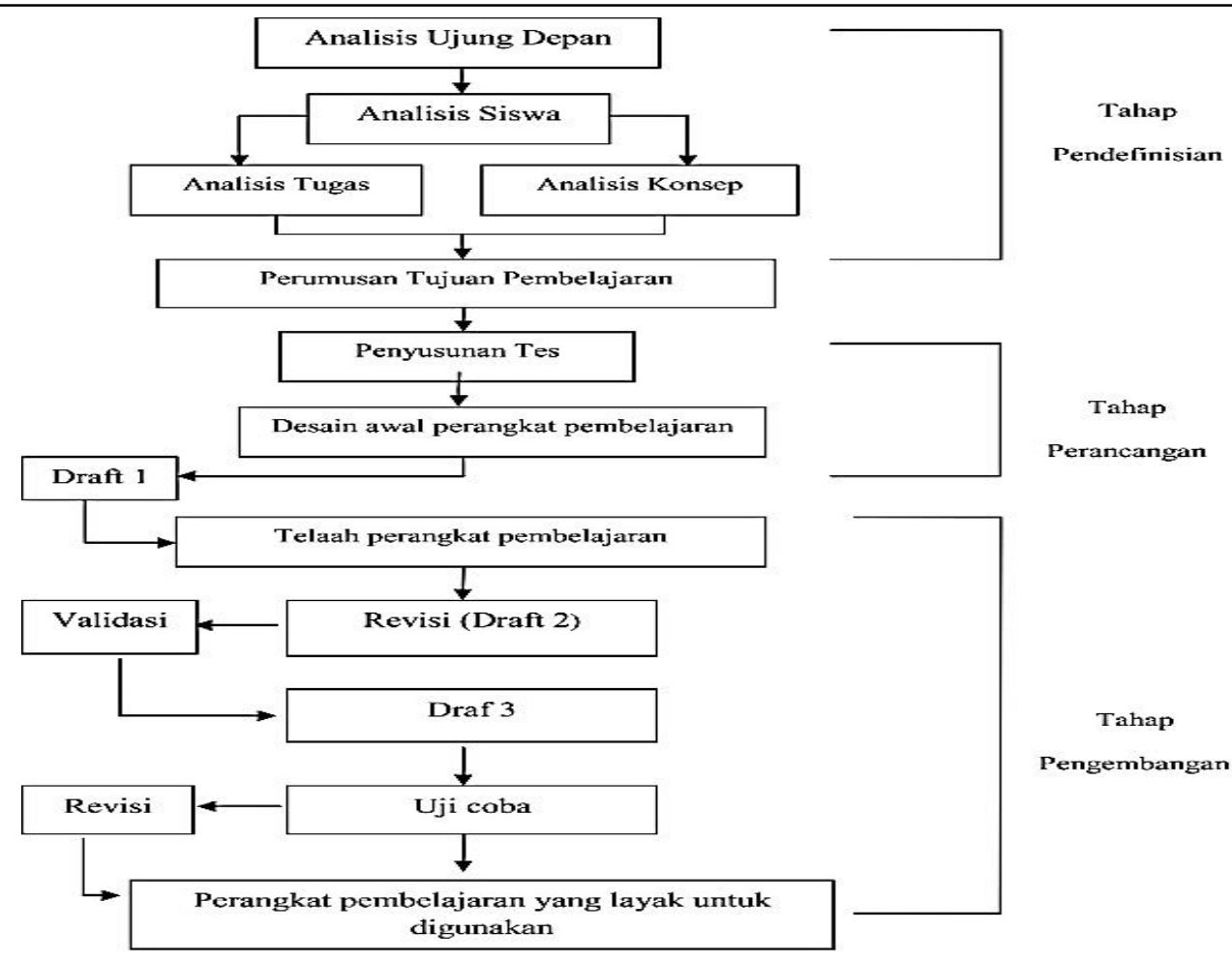

Gambar 1. Diagram Alur Tahap Pengembangan Perangkat(Diadaptasi dari, Ibrahim, 2002)

Ujicoba penelitian ini dilakukan pada 35 orang siswa kelas VII C SMP Negeri 31 Surabaya Tahun Pelajaran 2014-2015 dengan menggunakan rancangan penelitian One-Group Pretest-Postest Design, karena penelitian ini hanya menggunakan satu kelompok saja tanpa adanya kelompok pembanding. Instrumen penelitian ini kemudian di validasi oleh tiga pakar pendidikan. Teknik pengambilan data pada penelitian ini adalah dengan observasi, tes dan angket. Materi yang dikembangkan adalah materi pencemaran lingkungan.

\section{HASIL PENELITIAN DAN DISKUSI}

Berdasarkan hasil uji coba 2 perangkat pembelajaran yang telah dikembangkan dan diimplementasikan di SMP Negeri 31 Surabaya berupa, validasi perangkat, keterbacaan perangkat, keterlaksanaan pembelajaran, aktivitas siswa, hasil belajar siswa, respon siswa, dan keterampilan proses siswa akan ditampilakan berikut ini:

\section{A. Validitas Perangkat Pembalajaran}

Validasi perangkat pembelajaran yang dikembangkan diperoleh hasil sebagai berikut: validitas RPP pada setiap aspek yang dinilai diperoleh validitas RPP yang digunakan memenuhi dua kategori yaitu baik dan sangat baik. Validitas materi ajar yang digunakan memenuhi kategori valid. Validitas LKS yang meliputi aspek petunjuk, kebenaran isi, kemampuan keterampilan proses dengan model guided inquiry, prosedur, dan pertanyaan berkategori valid. Hasil validitas THB pada aspek validitas isi serta bahasa dan penulisan soal berkategori valid dan sangat valid.

\section{B. Kepraktisan Perangkat Pembelajaran}

Kepraktisan perangkat pembelajaran dalam penelitian ini ditinjau dari keterlaksanaan pembelajaran, keterbacaan materi ajar dan LKS, dan respon siswa.

1. Keterlaksanaan Pebelajaran

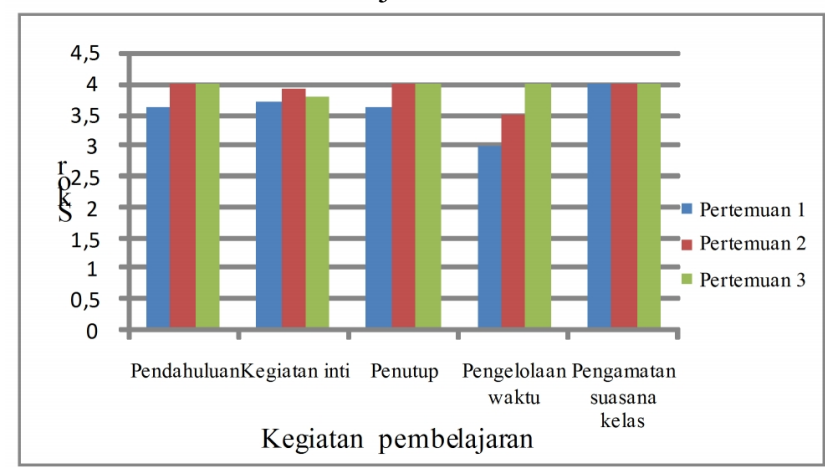

Gambar 2. Diagram Hasil Pengamatan Keterlaksanaan Pembelajaran

Keberhasilan proses pembelajaran didukung oleh adanya panduan yang dijadikan acuan oleh guru dalam mengelola kegiatan pembelajaran, dan RPP merupakan panduan yang digunakan guru untuk mengelola kegiatan pembelajaran. RPP merupakan salah satu perangkat pembelajaran yang dikembangkan oleh guru sebagai panduan dalam proses pembelajaran sebagaimana yang tercantum dalam PP No. 19/2005 tentang pedoman pengembangan perangkat pembelajaran kurikulum 2013. RPP sekurangkurangnya memuat tujuan pembelajaran, materi pembelajaran, indikator, metode pembelajaran, sumber belajar, dan penilaian hasilbelajar (Kemendikbud, 2013). 
Kegiatan pembelajaran dalam RPP yang dikembangkan meliputi kegiatan pendahuluan, inti, dan penutup. Kegiatan-kegiatan pembelajaran tersebut mencakup model, metode, dan sintak-sintak atau langkah-langkah pembelajaran. Sintak/langkah pembelajaran yang digunakan untuk mencapai tujuan pembelajaran yang telah ditetapkan atau kompetensi, mengacu pada model guided inquiry. Kepraktisan perangkat pembelajaran dapat diketahui dari keterlaksanaan RPP pada pertemuan pertama, kedua, dan ketiga yang terlaksana dengan baik.

\section{Keterbacaan Materi Ajar dan LKS}

Sugandi dalam Pratiwi, Sarwi, dan Handayani (2012) dalam proses pembelajaran, banyak komponen yang mempengaruhi hasil belajar. Komponenkomponen yang mempengaruhi hasil belajar, antara lain: tujuan, bahan atau materi yang dipelajari, strategi pembelajaran, siswa dan guru sebagai subjek belajar, media pembelajaran dan penunjang proses pembelajaran. Komponen-komponen tersebut saling terkait satu sama lain sehingga melemahnya satu komponen akan menghambat pencapaian tujuan pembelajaran secara maksimal.

Wujud dari pandangan konstruktivisme tentang pembelajaran yang baik yaitupembelajaran yang membelajarkan siswa pada partisipasi aktif siswa, dan menempatkan/memposisikan guru sebagai fasilitator (Westwood, 2008) dalam penelitian ini adalah dengan memfasilitasi siswa untuk belajar dengan menyediakan LKS sebagai panduan untuk melakukan pengukuran/pengamatan ataupun percobaan, dan melakukan diskusi. Siswa diberikan kesempatan untuk berinteraksi dengan materi yang dipelajarinya melalui pengamatan atau praktikum, diskusi, dan memberikan kesempatan kepada siswa untuk memikirkan hasil pengamatan atau praktikum, dan hasil diskusinya, sehingga melalui kegiatan tersebut, diharapkan siswa dapat mengembangkan keterampilan proses sains/inkuiri untuk meningkatkan pemahamannya terhadap materi atau konsep yang dipelajarinya.

Hasil penelitian tentang keterbacaan perangkat pembelajaran menunjukkan bahwa, materi yang termuat dalam LKS sesuai dengan konteks lingkungan yang sering ditemui oleh siswa dan sesuai dengan materi yang terdapat baik pada silabus maupun RPP, sehingga benar-benar mendukung untuk tercapainya kompetensi dasar dan melatihkan proses sains siswa. Lee (2006) menyatakan pendekatan kontekstual sangat diperlukan dalam pembelajaran, penyajian masalah kontekstual memiliki dua keutamaan yaitu meningkatkan motivasi belajar siswa sehingga siswa akan memberikan respon yang positif terhadap pembelajaran dan memberikan pemahaman yang baik pada materi yang diajarkan.
Respon siswa terhadap keterbaruan komponen materi/isi pelajaran dan materi ajar, rata-rata siswa merespon bahwa komponen tersebut baru, terdapat beberapa siswa yang menyatakan komponen tersebut tidak baru, karena berdasarkan kebijakan sekolah yang mengharuskan siswa untuk mengikuti kegiatan literasi (usaha meningkatkan wawasan siswa melalui membaca) sebelum KBM dimulai, peniliti berasumsi bahwa beberapa siswa tersebut sudah pernah membaca materi tentang pencemaran lingkungan yang termuat dalam materi ajar dan LKS, sehingga mereka merespon bahwa materi dalam perangkat pembelajaran tidak baru. Keterbacaan materi ajar dan LKS yang dikembangkan menunjukkan bahwa perangkat yang dikembangkan praktis digunakan dalam proses pembelajaran.

\section{Respon Siswa}

Pendapat siswa terhadap komponen-komponen perangkat pembelajaran dan model pembelajaran yang diberikan, siswa tertarik terhadap komponen pembelajaran yang diantaranya materi/isi pelajaran, LKS, materi ajar, cara guru mengajar, dan tahapantahapan yang dilakukan guru dalam proses pembelajaran. Respon siswa terhadap keterbaruan komponen materi/isi pelajaran dan materi ajar, rata-rata siswa merespon bahwa komponen tersebut baru, terdapat beberapa siswa yang menyatakan komponen tersebut tidak baru, karena berdasarkan kebijakan sekolah yang mengharuskan siswa untuk mengikuti kegiatan literasi (usaha meningkatkan wawasan siswa melalui membaca) sebelum KBM dimulai, peniliti berasumsi bahwa beberapa siswa tersebut sudah pernah membaca materi tentang pencemaran lingkungan yang termuat dalam materi ajar dan LKS, sehingga mereka merespon bahwa materi dalam perangkat pembelajaran tidak baru.

Respon siswa terhadap komponen keterampilan proses (merumuskan masalah, merumuskan hipotesis, pengamatan, menganalisis dan menarik kesimpulan) menunjukkan bahwa siswa merasa baru terhadap komponen tersebut. Hasil penelitian tentang respon siswa terhadap komponen-komponen keterampilan proses sains dan pentingnya melatihkan keterampilan proses sains sesuai dengan pernyataan Brum \& McKane (1989) yang menyatakan bahwa belajar IPA tidak dapat terlepas dari kemampuan untuk melakukan observasi, memformulasikan hipotesis yang testable, kemampuan untuk melakukan induksi dan deduksi, merancang dan melaksanakan eksperimen untuk membuktikan hipotesis.

Berdasarkan hasil analisis respon siswa terhadap pengembangan perangkat pembelajaran (yang meliputi: materi ajar dan lembar kegiatan siswa), serta pelaksanaan pembelajaran dengan model guided inquiry secara umum siswa merespon dengan kriteria 
sangat baik (Riduwan, 2010), sehingga respon siswa terhadap proses pembelajaran yang telah diikuti dinyatakan positif.

\section{Kefektifan Perangkat Pembelajaran}

Keefektifan perangkat pembelajaran yang dikembangkan ditinjau dari aktivitas siswa selama proses pembelajaran, hasil tes keterampilan proses sains siswa, dan hasil belajar kognitif siswa.

\section{Aktivitas Siswa}

Respon siswa yang positif terhadap pembelajaran yang diajarkan dengan perangkat yang telah dikembangkan sangat baik untuk memotivasi siswa untuk lebih aktif dalam pembelajaran. Aktivitas siswa sangat diperlukan dalam kegiatan pembelajaran karena akan berdampak pada hasil belajar siswa. Menurut Piaget (Slavin, 1994) perkembangan kognitif sebagian besar tergantung terhadap seberapa jauh anak aktif memanipulasi dan aktif berinteraksi dengan lingkungannya. Dengan memperhatikan siswa dalam pembelajaran seperti yang telah diuraikan di atas, dapat dikatakan bahwa pembelajaran yang dilaksanakan dengan menerapkan perangkat pembelajaran guided inquiry yang dikembangkan dapat melatih anak untuk terlibat aktif dalam pembelajaran sehingga berdampak terhadap hasil belajar yang baik pada aspek pemaham konsep dan ketarampilan proses sains siswa. Berikut disajikan gambar diakram aktivitas siswa selama proses pembelajaran.

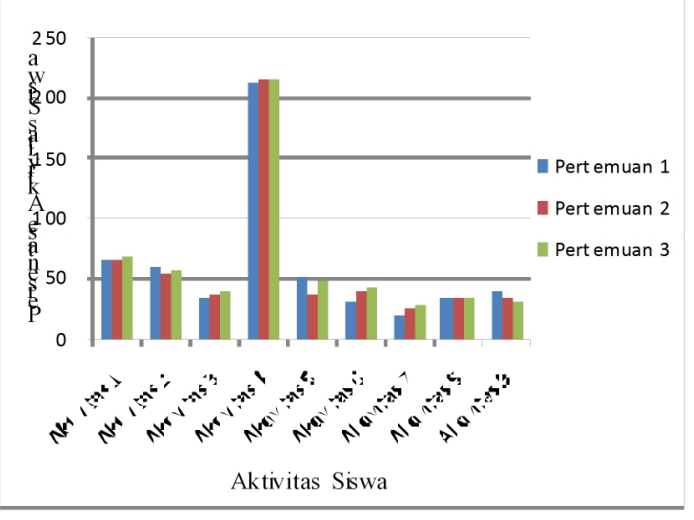

Gambar 3. Diagram Aktivitas Siswa

Guided inquiry sangat sesuai dengan tuntutan Kurikulum 2013 yang menginginkan agar proses pembelajaran hendaknya menggunakan metode scientific approch (pendekatan ilmiah) atau dalam IPA sering disebut keterampilan proses sains. Langkahlangkah pembelajaran guided inquiry memungkinkan siswa belajar secara aktif. Aktivitas siswa menunjukkan bahwa siswa memiliki keterlibatan yang cukup tinggi dalam kegiatan pembelajaran yang menggunakan perangkat pembelajaran guided inquiry. Aktivitas siswa yang tertinggi adalah berlatih keterampilan proses sains. Keterlibatan siswa yang tinggi tersebut nampak dalam latihan melalui kegiatan percobaan menggunakan LKS yang memuat keterampilan proses sains yang dibimbing oleh guru, yaitu dalam merumuskan masalah, merumuskan hipotesis, pengamatan, menganalisis dan membuat kesimpulan. Hasil uji coba perangkat ini sesuai dengan pernyataan Devi et.al (2009), yang mengemukakan bahwa kegiatan yang termuat dalam LKS menggambarkan tindakan atau aktivitas yang dilakukan siswa. Tindakan atau aktivitas tersebut merupakan sarana untuk melatih keterampilan proses sains siswa. Hal ini sejalan dengan pernyataan Astuti dan Setiawan (2013), bahwa melalui kegiatan dalam LKS yang memuat keterampilanketerampilan proses sains dan pertanyaan yang termuat (yang disajikan) dalam LKS dapat membantu siswa dalam mengembangkan keterampilan proses sains.

\section{Hasil Tes Keterampilan Proses Sains Siswa}

Komponen-komponen keterampilan proses sains yang dilatihkan dalam perangkat pembelajaran yang dikembangkan meliputi: merumuskan pertanyaan, merumuskan hipotesis, pengamatan, menganalisis, dan menyimpulkan. Keterampilan proses sains dalam merumuskan pertanyaan meningkat, keterampilan proses sains dilatihkan melalui kegiatan percobaan menggunakan LKS yang dikembangkan meningkat dengan kategori baik. Pada LKS I, siswa dilatihkan keterampilan merumuskan pertanyaan, berhipotesis, mengamati, menganalisis, dan menyimpulkan dengan memberikan contoh keterampilan-keterampilan tersebut dalam LKS. Selanjutnya pada LKS II dan LKS III siswa melakukan percobaan secara mandiri namun tetap melalui bimbingan guru sehingga kegiatan siswa dalam berlatih keterampilan proses sains dapat terlaksana dengan baik, meskipun terdapat kendala yang dialami siswa dalam menyimpulkan, namun hasil ujicoba menunjukkan keterampilan siswa dalam menyimpulkan meningkat.Hasil keterampilan proses sains siswa dalam mengerjakan LKS digambarkan sebagai berikut:

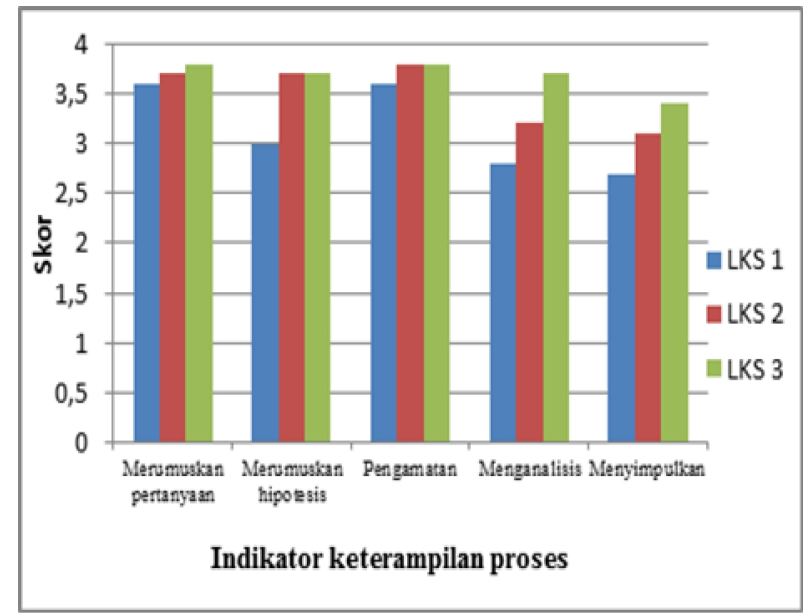

Gambar 4. Diagram Kemampuan Keterampilan Proses Sains dalam Mengerjakan LKS 
Komponen-komponen keterampilan proses yang termuat dalam LKS memungkinkan siswa untuk lebih aktif dalam pembelajaran, sehingga melalui kegiatan tersebut, siswa diberikan kesempatan untuk berinteraksi dengan materi yang dipelajarinya melalui pengamatan atau praktikum, diskusi, dan memberikan kesempatan kepada siswa untuk memikirkan hasil pengamatan atau praktikum, dan hasil diskusinya, sehingga melalui kegiatan tersebut, diharapkan siswa dapat mengembangkan keterampilan proses sains mereka dari materi yang telah mereka pelajari. Keterampilan proses sains siswa diamati melaui aktivitas siswa selama mengerjakan LKS dan untuk mengetahui sejauh mana siswa memahami keterampilan-keterampilan proses yang dijadikan tujuan dalam penelitian ini, siswa diberikan tes kognitif keterampilan proses. Keterampilan proses sains memuat dua aspek keterampilan yaitu 1) keterampilan dari sisi kognitif dan 2) keterampilan proses dari aspek aktivitas siswa. Hasil keterampilan proses sains siswa (kognitif) digambarkan sebagai berikut:

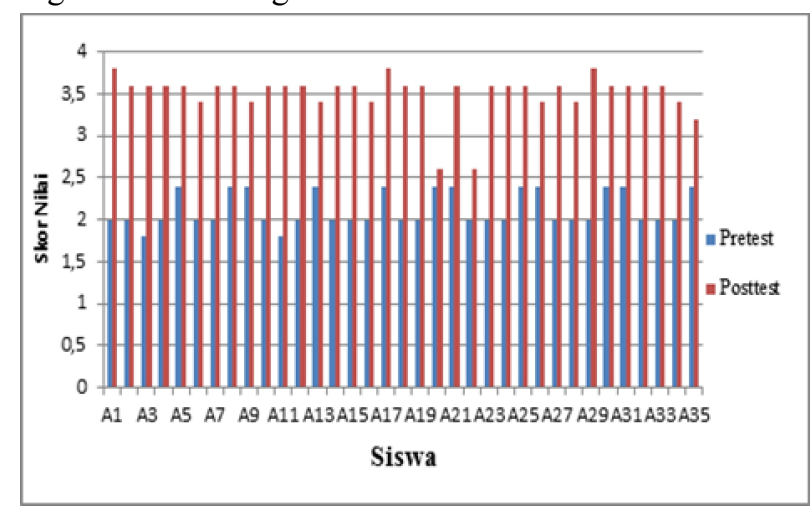

Gambar 5. Diagram Kemampuan Keterampilan Proses Sains (Kognitif)

Keterampilan dari sisi kognitif sebagai keterampilan intelektual atau keterampilan dasar yang melatarbelakangi penguasaan keterampilan proses sains yaitu penguasaan siswa tentang konsep materi yang diajarkan. Berdasarkan hasil tes keterampilan proses siswa, secara umum keterampilan proses sains siswa tuntas secara klasikal. Hal ini menunjukkan bahwa implementasi pembelajaran yang dilakukan guru sudah efektif dalam membelajarkan keterampilan proses sains siswa, pendapat senada juga disampaikan oleh Semiawan (1992), untuk membelajarkan keterampilan proses sains siswa hendaknya didorong untuk mengobservasi (menghitung, mengukur, mengklasifikasi), mencari hubungan ruang/waktu, membuat hipotesis, merencanakan penelitian, mengendalikan variabel, interpretasi, menyusun kesimpulan sementara, meramalkan, menerapkan dan mengkomunikasikan.

Berdasarkan sintaks pembelajaran guided inqury yang diterapkan guru di dalam kelas, siswa lebih ditekankan untuk lebih banyak berinteraksi dengan guru maupun siswa dalam bentuk mengajukan pertanyaan, berhipotesis, mengamati, menganalisis hasil pengamatan yang telah mereka lakukan serta mengkomunikasikan kesimpulan yang telah mereka buat berdasarkan hasil pengamatan mereka sehingga dapat dinyatakan bahwa pembelajaran guided inquiry sangat baik untuk melatihkan keterampilan proses sains siswa.

Keterampilan proses sains dari aspek aktivitas siswa selama mengerjakan LKS observasi mendapatkan rerata nilai tinggi, dalam penelitian ini aktivitas siswa yang diamati adalah merumuskan pertanyaan, merumuskan hipotesis, mengamati objek, menganalisis dan membuat kesimpulan. Hal senada juga disampaikan oleh Ebel \& Frisbie dalam Subali (2010) yang menyatakan bahwa tes tertulis tidak dapat untuk mengukur performans, tetapi tetap berguna untuk mengukur penguasaan basis pengetahuan, termasuk basis pengetahuan bagi peserta didik untuk menampilkan performansnya.

\section{Hasil Belajar Kognitif}

Implikasi dari aktivitas siswa dalam berlatih keterampilan proses sains adalah meningkatnya hasil belajar kognitif siswa yang secara umum didapatkan kategori ketuntasan klasikal maupun individu siswa setelah dibelajarkan menggunakan perangkat pembelajaran guided inqury dapat dinyatakan tuntas dengan kategori tinggi, hasil tersebut mnunjukkan bahawa pembelajaran guided inqury efektif dalam meningkatkan hasil belajar kognitif siswa. Berikut disajikan gambar diagram tes hasil belajar kognitif siswa:

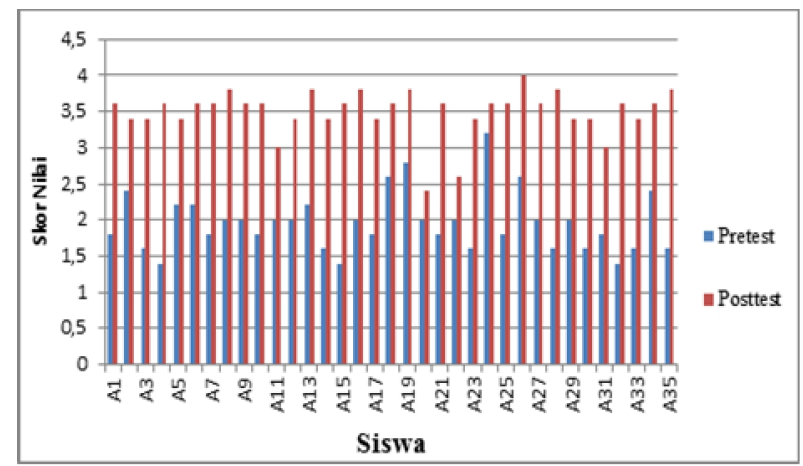

Gambar 6. Diagram Tes Hasil Belajar Siswa

Efektif atau berpengaruhnya pembelajaran guided inqury yang telah dilaksanakan didukung oleh hasil analisis sensitivitas soal, dan analisis $N$-Gain, yaitu butir soal secara umumsensitif, sedangkan untuk $\mathrm{N}$-gain hasil belajar siswa secara klasikal maupun individu dinyatakan tuntas (berkategori tinggi). Hasil analisis tersebut menunjukkan bahwa hasil belajar yang diperoleh siswa sebelum dan sesudah pembelajaran menunjukkan perbedaan yang signifikan. 
Perbedaan skor pretest dan posttest ini menunjukkan bahwa terdapat pengaruh atau dampak pembelajaran guided inquiry terhadap hasil belajar siswa. Dengan melakukan kegiatan pretest guru dapat mengetahui pengetahuan awal siswa terhadap materi ajar sehingga dalam pembelajaran guru dapat memberi treatmen yang tepat untuk memperbaiki pemahaman siswa jika terdapat indikasi miskonsepsi dari hasil pretest yang didapatkan.

Hasil ini juga tidak terlepes dari kevalidan dan kepraktisan perangkat pembelajaran yang digunakan seperti RPP, LKS, Materi Ajar, dan instrumen penilaian hasil belajar kognitif yang membantu siswa dalam meningkatkan hasil belajar mereka, hal ini ditunjukkan oleh hasil postest siswa yang mendapatkan rata-rata nilai dengan kategori tuntas. Pencapaian ini menunjukkan bahwa pembelajaran IPA menggunakan perangkat model guided inquiry yang melatihkan keterampilan proses sains yang dikembangkan berpengaruh terhadap hasil belajar pengetahuan peserta didik. Piaget (Hughes, 2012) menemukan bahwa perkembangan kognitif sebagian besar bergantung pada seberapa jauh anak akanaktif berinteraksi dengan lingkungannya. Penyajian pengetahuan dengan mendorong siswa menemukan sendiri pengetahuan tersebut dilakukan melalui interaksi inkuiri terbimbingdi dalam kelas.

Atas dasar uraian hasil penelitian di atas maka didapatkan: perangkat pembelajaran (RPP, LKS, materi ajar, dan Tes Hasil Belajar) layak digunakan dalam proses pembelajaran yang didukung oleh; keterlaksanaan pembelajaran, keterbacaan LKS dan materi ajar, serta respon siswa berkategori baik; keterampilan proses sains siswa dalam mengerjakan LKS berkategori tinggi yang dapat dinilai melalui aktivitas siswa; aktivitas siswa kategori baik dengan aktivitas yang paling menonjol adalah keterampilan proses sains; hasil belajar siswa mengalami peningkatan setelah penerapan perangkat pembelajaran yang dikembangkan dengan model guided inquiry.

\section{PENUTUP}

\section{A. Simpulan}

Berdasarkan hasil penelitian yang telah dilakukan, maka dapat disimpulkan bahwa perangkat pembelajaran IPA model guided inqury layak untuk melatih keterampilan proses sains dan meningkatkan hasil belajar siswa SMP.

\section{B. Saran}

1. Disarankan dalam pelaksanaan pembelajaran model guided inquiry perlu memperhatikan pengelolaan waktu dan persiapan, agar pembelajaran dapat terlaksana dengan baik.

\section{REFERENSI}

Astuti dan Setiawan, 2013. Pengembangan Lembar Kerja Siswa (LKS) Berbasis Pendekatan Inkuiri Terbimbing dalam Pembelajaran Kooperatif pada Materi Kalor. Jurnal Pendidikan IPA Indonesia FMIPA UNNES Semarang, JPII 2 (1) (2013) 88 - 92.

Brum \& McKane. (1989). Study guide biology: Exploring life. New York: John Wiley \& Sons.

Depdiknas. (2004). Penyusunan Perangkat Pembelajaran. Jakarta: Depdiknas.

Devi, Sofiraeni dan Khairuddin, 2009. Pengembangan Perangkat Pembelajaran untuk Guru SMP. Jakarta: (PPPPTK IPA) untuk Program Bermutu.

Heuvelen, A.V. 2001. Millikan Lecture 1999: The Workplace, Student Minds, and Physics Learning Systems . Am.J. Phys. 69 (11)

Hughes, A.G. dan E.G. Hughes, 2012. Learning and Teaching: Pengantar Psikologi Pembelajaran Modern, PenerbitNuansa, Bandung.

Ibrahim, M. (2002). Pengembangan Perangkat Pembelajaran. Modul Disajikan pada Pelatihan Terintegrasi Berbasis Kompetensi Guru mata Pelajaran Biologi SLTP. Jakarta: Dirjen Dikdasmen Depdiknas

Ibrahim, Nur, dan Kasdi, A,. (2010). Dasar-dasar Proses Belajar Mengajar. Surabaya: Unesa University Press.

Kemendikbud. (2013). KURIKULUM 2013. Jakarta: Badan Penelitian dan Pengembangan.

Kuhlthau \& Todd. (2007). Guided Inquiry: A framework for learning through school librariesin 21st century schools. New Jersey: CISSL.(Online).(http://cissl.-scils. rutgers. edu/guided inquiry /introduction.- html .htm, diakses tanggal 5 Desember . 2014).

Lee, Miha. 2006. What does constructivism suggest for science education. Northridge: California State University.

Mustahal, (2014). Pengembangan Perangkat Pembelajaran IPA Model Guided Inquiry untuk Melatihkan Keterampilan Proses Sains dan Meningkatkan Hasil Belajar Siswa. Surabaya: UNESA

Olson, Steve. 2013. Inkuiri dan Standar-standar Pendidikan Sains Nasional, Sebuah Panduan untuk Pengajaran dan Pembelajaran. Bandung: SEAMEO QITEP.

Praptiwi, L. Sarwi, dan Handayani, L. (2012). "Efektivitas model pembelajaran eksperimen inkuiri terbimbing berbantuan my own dictionary untukmeningkatkan penguasaan konsep dan unjuk kerja siswa SMP RSBI”. 
UNNES science education journal. Vol.1 No.2, pp. 86-95.

Riduwan. (2010). Skala pengukuran variabel-variabel penelitian. Bandung: Alfabeta.

Semiawan, C.R. (1998). Pendidikan Tinggi: Peningkatan Kemampuan Manusia Sepanjang Hayat Seoptimal Mungkin. Jakarta: Dirjen Dikti Depdikbud.

Slavin, Robert E. (1994). Cooperative Learning, Teori, Riset, dan Praktik(Terjemahan). Bandung: Nusa Media.
Subali (2010). Pengukuran keterampilan proses sains pola divergen mata pelajaran biologi SMA di provinsi DIY dan Jawa Tengah. Prosiding seminar nasional biologi. ISBN: 978-60297298-0-1. Yogyakarta: UNY.

Supriyono, Agus. 2009. Cooperative Learning Teori dan Aplikasi PAIKEM. Yogyakarta: Pustaka Pelajar.

Westwood. (2008). What Teacher Need to Know about Teaching Method. Australia: Acer Press. 